\title{
READERS
}

Journal of Management Info (JMI)

ISSN:2313-3376

www.readersinsight.net/jmi

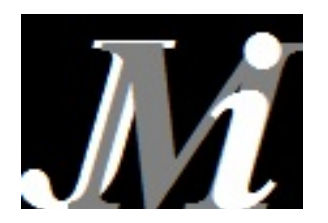

\section{Service quality in higher education: Study of Turkish students in Malaysian universities}

\author{
Amran Rasli*1, Mansoor Nazir Bhatti ${ }^{2}$, Nadhirah Norhalim ${ }^{3}$, Tan Owee Kowang ${ }^{4}$ \\ ${ }^{1,2,3,4}$ Faculty of Management, Universiti Teknologi Malaysia
}

* Corresponding author: amrasli@gamil.com

Abstract

The Article attempts to analyze service quality in higher education institutions of Malaysia. Study used Gap Model presented by Parasuraman et al. $(1985,1988)$ to identify difference between expected quality and perceived quality in higher education institutions of Malaysia. Study focused to identify gaps of Turkish students in Malaysian universities Five basic dimensions of service quality measured through SERVQUAL (Instrument for service quality measurement). These dimensions are tangibles, reliability, responsiveness, assurance, and empathy. A stratified sample of 41 Turkish students has been selected from top five public universities in Malaysia. Results showed negative service quality gap in higher education institutions of Malaysia from Turkish students' perception which indicated perceived service quality is below than expectations of Turkish students in Malaysian universities.

Keywords: Service Quality, Gap Model, Instrument, Perception, Expectation, Tangibles, Reliability, Responsiveness, Assurance, Empathy.

\section{ARTICLE INFORMATION}

$\begin{array}{ll}\text { Received: } & 25 \text { March } 2014 \\ \text { Revised: } & 25 \text { July } 2014\end{array}$

Accepted: 25 August 2014

DOI: https://doi.org/10.31580/jmi.v3i1.9

\section{Introduction}

According to UNESCO (2009) and Naidoo (2009), the numbers of students who are studying abroad in the past decades have been growing from 150,000 to 2.8 million since 1955 to 2007 . This phenomenon can be seen as an emerging perspective of internationalization or "massification" of education to increase the higher institution's influence, visibility, and/or market share at the international level (Gibbons, 1998; Denman, 2005) which inevitably opened up many options for students to study abroad (Markovic, 2005).

This phenomenon is also impacting Turkish students. According to Edufairs (2013) Turkish students have a tendency to study abroad in order to improve their English and Foreign language skills as well as the lack of space in domestic universities. In addition, the expensive tuition fees in private Turkish universities (up to 25,000 USD per year) and poor foreign language preparation in domestic schools mean that Turkish students are inadequately prepared for an international job market after graduation. It is a common perception that education acquired abroad is prestigious thus giving students an edge over their fellow colleagues in the domestic job market (Leggott and Stapleford, 2007) and can ensure a better starting position and salary when applying for jobs at home. Finally, for some Turkish students, like other international students as well, studying abroad can give valuable life experience and expand their worldview. Malaysia, as a developing country in South East Asia, is equally affected with the challenges of globalization and internationalization of education. Two of the strategies to response to these challenges from the Malaysian government have been to allow international students to study in public higher education institutions (Acuma Incorporated, 2009) and to improve the quality of tertiary education in Malaysia (Ministry of Higher Education Malaysia, 2006) to turn Malaysia into an international hub and centre of excellence in education. In addition, according to (Johari et al., 2002), the engineering education model developed for Malaysia is expected to be capable of achieving global recognition and accreditation for excellence in engineering practice as well as educating future leaders. The attractiveness of the engineering programs offered by most of the public Malaysian universities is further enhanced with accreditation from international bodies for the engineering courses.

The number of international students in Malaysia is crucial for the national economy, particularly if considered as provider of higher quality education in the global market. In other words, higher education in Malaysia where English is widely used in teaching due to the legacy of the British Empire, has the potential to be a major revenue earner through the offering of world class academic programs (Jimenez, 2007). The targets identified include developed nation such as China, as well as developing nations such as Iran, Indonesia, Vietnam and the Middle East, countries which are attracted by Malaysia's first-rate higher education, relatively low tuition fees, its harmonious multicultural society, political stability and the widespread use of English. The Internet facilities in Malaysia become the main Government's initiative and to be utilized as a catalyst for developing the nation's socio-economic status, education, healthcare and other services (Harris, 2007). Therefor most of the Universities in Malaysia highly committed in implementing the e-Learning throughout the campus as part of the program to accommodate the teaching and learning trend and demand. The establishment of a National Institute of e-Learning under the auspices of Ministry of Higher Education is the step in providing guidance in the formulation of e-Learning policies and in coordinating and monitoring the implementation of e-Learning (Hanafi Atan, Mohamed Amin Embi and Supyan Hussin, 2011). Accordingly, the aim of the Ministry of Higher Education in Malaysia is to attract 80,000 international 
students to study in Malaysia by 2010 (Sirat, 2006); a target which had been duly achieved.

Graduate student enrollment in the early years of graduate education in Malaysia was made up mainly of Malaysians and they were few in number. Their number grew gradually as more graduate schools were set up, but still, with few international students. Lately, however, the scenario has changed. The early groups of international graduate students to arrive in Malaysian came from neighboring countries such as Indonesia, which are less developed than Malaysia. In the recent past, however, more international students were arriving from further afield - from countries in the Indian subcontinent and the Middle-East and North African countries or MENA (Ayob and Yaakub, 2000). Upon greater scrutiny, the influx of students from Turkey is encouraging. Turkish students who used to make America and Europe their top destination for further studies are slowly turning to Malaysian universities. As more and more Turkish students inquire about further studies option in Malaysia, a review of the quality of services rendered by the Malaysian universities to them becomes timely. As such, this exploratory study seeks to understand the influx of Turkish students to Malaysian universities from the service quality perspective.

\section{The impact of $9 / 11$}

The tragedy of the mega-terrorist attack on the World Trade Center (WTC), U.S. in September 112001 left an ever-lasting impact on the world. Immediately after the WTC tragedy, both the U.S. government and American mass media, Cable News Network (CNN) in particularly, blamed to Islamic fundamentalism and seemed to have viewed Islam as the enemy and the attack as an attack on Western civilization, even before any credible evidence was gathered, consciously or unconsciously (Farouk, 2002). When the U.S. planned to attack Afghanistan to arrest the Al-Qaeda terrorists and punish the Taliban regime for attacking them, Malaysia's Prime Minister at that time, Mahathir Mohamad was the first leader in the world to criticize U.S. on the humanitarian grounds arguing that it would lead to unnecessary and unacceptable civilian casualties (Farouk, 2002). Due to Mahathir's courage to speak up against the U.S. on this issue, Malaysia has gained the popularity in the world especially among the Muslims, as an independent Islamic country that has a strong identity and willingness to champion the plights of the Muslims.

As the consequences of this incident, Malaysia has gained high recognition among most Islamic countries in the world which turned out as the major deciding factor for international students, especially those from MENA to study in Malaysia. This was proven by the increasing enrollment of MENA students in Malaysia from 2003 onwards, both in public and private universities. Table 1 showed the breakdown of MENA students in accordance to their countries of origin. Another pulling factor was the global financial crisis in which the values of the USD and Euro currencies appreciated, thus causing the costs of studying and living in Malaysia to become relatively lower than other countries, especially the Western countries.

Table 1: Breakdown of MENA students in accordance to their countries of origin

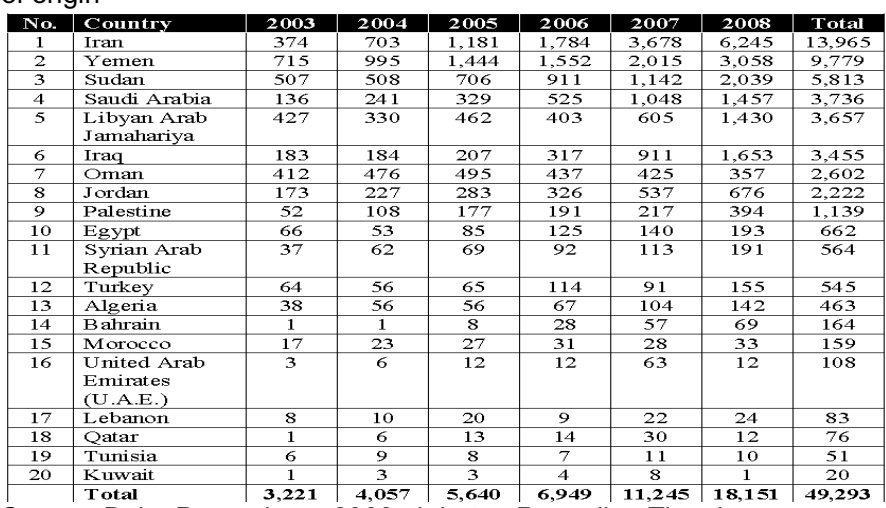

Source: Buku Perangkaan 2008, Jabatan Pengajian Tinggi
In line with the impact of global financial crisis, Malaysia Embassy in MENA conducted strong promotion efforts on Malaysia as a preferred destination for higher education has successfully increase the enrollment of MEA students in Malaysia in year 2008. Malaysia Embassy had set up an education unit since year 2003 in Saudi Arabia to promote the education in Malaysia through promotions and seminars and it has seen a significant growth in the number of enrollment. In addition, Malaysia has increasingly become the destination for education of other Asian students due to the factors of high costs and concerns about discrimination in Western countries, and shared values among the Asians which they find it more comfortable with (IDEAS, 2008). Thus, there was a significant increase in the total number of foreign students coming to Malaysia especially from the Middle East and North Africa (MENA) region to pursue their higher education in year 2008, in equivalent with 40 percent increase compared with year 2007.

\section{The Turkish factor}

Turkey's young population and increasing income makes it an attractive market for global educational institutions. Based on research conducted by Edufairs Recruitment Tour Turkey, approximately 55,000 Turkish students go abroad annually for educational purposes (McPherson, 2013). Attending to Turkish universities is only possible by taking the University Student Selection Examination (ÖSYS) in Turkey (Karakaya and Tavşancil, 2008). Clark and Mihael (2012) provides this insight on the educational system by explaining that in 2011, 1,692,000 high school graduates took the national Student Selection Exam (ÖSS) and compete for only 400,000 entrance positions in post-secondary institutions in Turkey (McPherson, 2013). Although a high percentage of the students qualify for entrance into domestic universities, this translates into less than 33 percent of students successfully being placed. Education is one of the most competitive markets in Turkey, for both consumers and suppliers. Educators race over each other to compete for the top students while students race within themselves for top education (Mehmet Tuğcu, 2010).

Due to capacity and quality constraints of the Turkish education system, Turkish students have a long history of travelling abroad for higher education. According to Clark and Mihael (2012), over 65,000 Turkish students were studying abroad in 2010 and the top five destinations were: Germany (37.8 percent of all international students), the United States (15.6), the United Kingdom (5.6), Austria (3.7) and France (2.9). For those whose families can afford it, studying abroad can be a different avenue to earning a prestigious degree, putting students in line for the best jobs when they return home. Since the university system in Malaysia uses English and the tuition fees are generally much lower than universities in Europe and America, there has been a significant positive trend of Turkish students studying in Malaysia (refer Table 1). However, students upon arrival at the university abroad face problems in adjusting to the new environment and facing reality of the differences in their perception and expectation of the university which could affect their satisfaction in the long run.

\section{Adjustment issues}

Adjustment to a new environment involves several disciplines such as psychology, sociology, and anthropology. When a person is in contact with a new environment, it is unavoidable that he/she will face certain level of difficulties or stress. To overcome this, he/she has to adjust to the new environment. In short, adjustment is: "the behavioral process of balancing conflicting needs and the obstacles between the individual and the circumstance" (Arkoff, 1968). Halonen and Santrock (1997) sees 'adjustment' as a psychological process for individuals to adapt to a new environment through managing the problems, needs, behaviors, and requirements of daily life.

Adjustment exists in two levels - the individual level and the group level. At the individual level, adjustment is a process to decrease psychological stress effectively. At the group level, it becomes a social learning process to interact with the host socio-cultural 
environment (Ward and Rana-Deuba, 1999). Also, Ward and Kennedy (1994) used to relate the acculturation theory to both psychological and socio-cultural aspects of adjustment. However, some researchers feel that such segregation is inappropriate. This is because, according to Maslow's hierarchy of needs, individuals' emotional needs such as safety needs and longing for love greatly influence their ability to adjust. Hence, it is actually a mixture of psychological and sociocultural elements (Brown and Holloway, 2008).

As a social issue, a number of researchers have paid attention on adjustment issues faced by oversea students (Mehdizadeh and Scott, 2005; Reynolds, 2010; Zhu, 2012). To adjust to a new environment is often a big issue for overseas students, not forgetting that this is a time-consuming process. Based on the previous research by Fang (2010), $85 \%$ oversea students felt that the culture of the host country is different from their homeland. In that study, only $10.5 \%$ respondents were able to adjust to their host culture within three months, and $21.1 \%$ needed more than one year.

\section{Acculturation theory}

A society's cultural acculturation issue only started to gain scientific attention in 1918 due to its involvement in different time periods and fields such as psychology, anthropology, and sociology. Since then, numerous theories and definitions have been combined to describe the elements of the acculturative process (Rudmin, 2003). The acculturation theory was introduced by John Schumann as a second language acquisition theory in 1978. It can be described as how the socio-cultural perspective affects the learner on picking up a second or target language (Schumann, 1978). The theory insists that there are certain socio-cultural factors that can impact the learning of second or target language; the impact may inhibit or promote the language acquisition, and this has been studied by Ellis (1994). This theory identifies that people need to pay more attention in the aspect of how social and psychological factors involve language teaching and learning rather than the nature of a language or psychological process necessary to acquire a language.

Acculturation plays an important role in this model because it is a cluster of social-psychological factors (Schumann, 1978, 1990). Acculturation is: "the behavior changing process in culture adoption led by social environment change and psychological change" (Sam and Berry, 2010). In other words, it involves behavioral changes in a person due to his/her union with different cultures or when he/she encounters a new culture that has been instilled into his/her thought and behavior.

Gordon (1964), on the other hand, has given seven stages in the model of assimilation between cultures. The initial stage is acculturation. At this stage, the individuals are trying to adjust their cultural values and daily norms in their host society in terms of language, clothes, and day-to-day customs. The subsequent stages are social structural integration by volume cliques, marital assimilation by broad intercultural marriage, identification and integration by host cultural oriented guiding, attitude reception integration by fully understanding each other, integrated behavior reception by widespread homage, and lastly civic integration by peace of mind. Figure 1 presents a relationship framework to understand acculturation between original culture $\mathrm{A}$ and $\mathrm{B}$. It shows that acculturation starts when the cultures come into contact with each other. The influence of acculturation can be categorized into two divisional levels of change: group and individual. At group level, it involves social environment changes that can result in integration of the two cultures. Meanwhile, at the individual level, cultural integration leads to acculturative stress and individual routine behavior changes; this can bring psychological changes and complete adaption to the individual.

Brown (1994) indicated that, "a person's worldview, self-identity and systems of thinking, acting, feeling, values, beliefs, perceptions and communicating can be disrupted by a change from one culture to another" (p. 163). He pointed out four successive stages of

acculturation: euphoria, culture shock, culture stress, and full recovery; these are shown in Figure 2.

CULTURAL/GROUP LEVEL

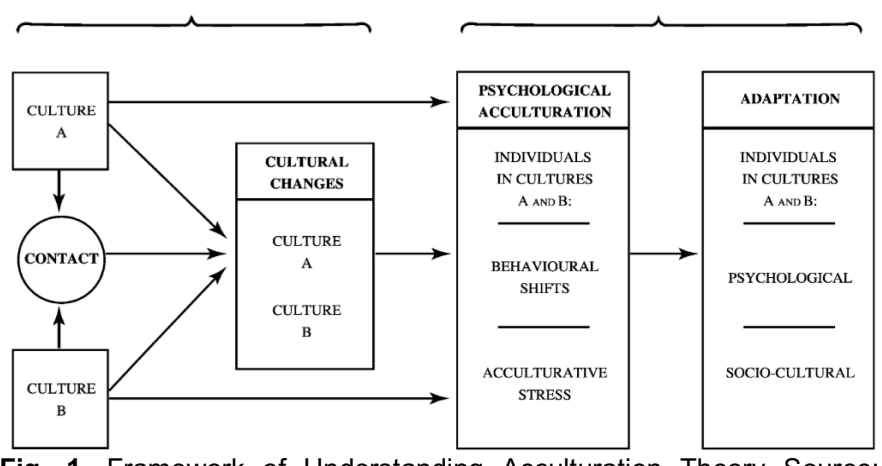

Fig. 1. Framework of Understanding Acculturation Theory Source: Berry (2005)

Brown's four successive stages of acculturation is a dynamic process that explains the adjustment issue faced by international students during their scholastic life outside of their homeland. Better adaption to a new culture is important to reduce the students' cultural stress and boost up their concentration on their studies (Ward, 1999). Therefore, HEIs have to provide all the necessary supports to assist international students to adapt to the host culture and surrounding.

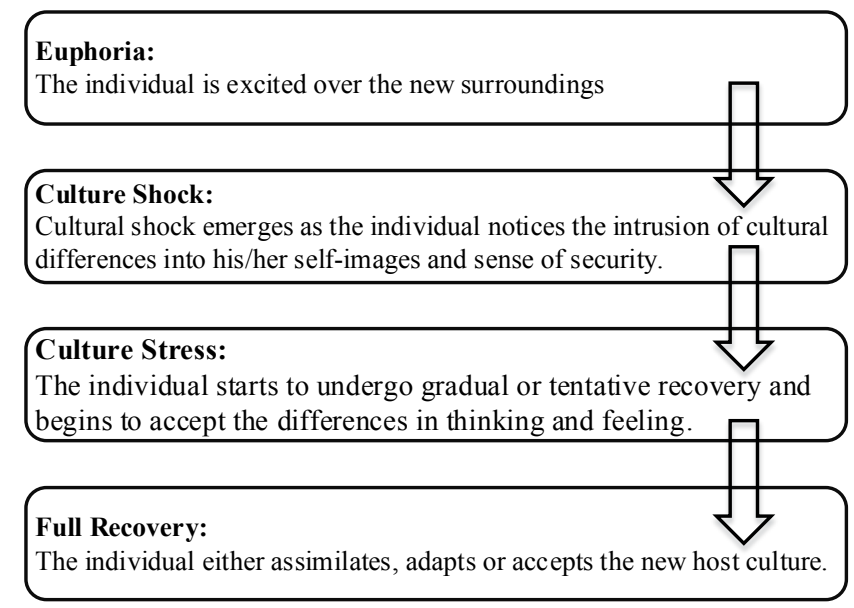

Fig. 2. Brown's Four Successive Stages of Acculturation Source: Brown (1994)

\section{Service quality}

Providing excellent and satisfactory service quality is a great challenge for the modern service industry (Hung et al., 2003). Seymour (1993) advocated that providing high quality service is one of ways to maintain the market share. According to Massy, Wilger and Colbeck (1994), consumers should be the center of quality management. As such, organizations should continuously try to fulfill their customers' expectation and minimize the service quality gaps (Parasuraman et al., 1985) and maintain their competitive advantage. In this context, both Brochado (2009) and Negi (2007) believed that provision of quality services is critical for achieving success by higher education institutions. Accordingly, the aforementioned argument holds true particularly for HEIs in developing countries which face intense competition from foreign HEIs, particularly with the establishment of offshore foreign campuses worldwide.

Service quality is a global evaluation or attitude of overall excellence of services (Parasuraman et al., 1985) that measures how well a delivered service matches the customers' expectations (Lewis and Booms, 1983). Cronin and Taylor (1992) hold a different view on the significant of expectations and advocated that service quality is about 
how the customers think of the actual service performance and process. Parasuraman et al. (1985) opined that service quality is more difficult to measure than quality of goods quality, service quality performance result is the comparison between expectations and perceptions by consumers; and service quality concerns the outcome and the process of a service.

\section{Service quality in the education sector}

The service quality in the education sector is strongly affected by customer orientation like other sectors. However, not many HEIs can recognize this fact, and worse still, some do not see that they are providing services to their consumers, i.e., the students (Lewis and Smith, 1994). Grönroos (2000) advocated that the customers should be considered as a critical component in this service system. According to Chang (2008) the concept of service quality should be generally viewed from the customers' perspectives, due to customers' differences in values, ground of assessment and circumstances. The debate on service quality and customer satisfaction has received significant attention in the extant literature (Eshgi, et al. 2008). Hawes and Glisan (1983) put forward that students are the customers in higher education sector, and thus, the HEIs should take care of their needs and expectations. Moreover, to a certain extent, the quality of education is reflected by the level of services. The service quality is a crucial issue in service marketing that, if done brilliantly, can distinguish a HEI from its competitors even at the global arena. The service quality of HEIs ought to be treated as a part of national development strategy, especially in developing countries such as Malaysia (Anantha, 2012).

Looking at their characteristics, higher education institutions are argued to be service providers (Brochado, 2009; Cuthbert, 1996). According to Brochado (2009) services provided by higher education institutions are intangible whose production and consumption occurs simultaneously. Students, regarded as customers, play a dual role in the process, i.e. as participants and consumers of the services provided (Negi, 2007). While paying for enrollment fees, the students are also paying for the institutional services such as accommodation, food, library, stadium, shuttle bus, network service and security services. Clearly, improving these facilities and services can significantly attract highly qualified students (Taiwo, 2010).

Saadiatul, Samsinar and Wong (2000) conducted a research using SERVQUAL measurement to assessing the service quality of Malaysian HEIs. SERVQUAL measurement is a standard instrument used to evaluate and identify the service quality status quo to understand the weakness before making improvement. Results generally indicated that students are not satisfied with the service quality HEIs provided because they have failed to fulfill all five dimensions used to measure students' perception. In order to survive and become outstanding in the international market competition, all HEIs need to pay particular attention to their service quality (Mishra, 2006). Parasuraman et al. (1985) found that satisfied services are the services that can meet or exceed consumers' expectation. The SERVQUAL instrument has been widely used (Shekarchizadeh et al. 2011; Zeshan, 2010) in higher education, to measure consumers' expectations and perceptions of service quality. Arising from the gaps model of service quality, Parasuraman et al. (1985) proposed the SERVQUAL instrument as a standardized tool for measuring service quality based on five dimensions: tangibles, reliability, assurance, empathy and responsiveness. It was tested for reliability and validity in multiple service sector settings, including higher education institutions (HEIs) and it was found to be a concise multi-item scale with good reliability (.92) and validity (Cuthbert, 1996; Souter and McNeil, 1996; Saaditul et al. 2000).

\section{GAP model}

The GAP model, was developed by Parasuraman, Zeithaml and Berry in 1985. It is the most widely used model for investigating the inequalities between expected quality and perceived quality by consumers in the service sector. A gap arises when the actual perceived service does not meet expectation. Improvement of service quality can lead to competitive advantage (Gouthier and Schmid,
2003). In other words, this service quality model is used to analyze the root causes of quality issues and find the appropriate measures to eliminate the gap. It can be implementing for any service provider (Parasuraman et al., 1988), and is also used in this research. This service quality model is shown in Figure 3.

This model presents how the service quality forms. The upper part of GAP model shows customer-related issues, and the main issue here is the expected service and perceived service. The expectation of service is a function of the customer's actual experience, personal needs, and the reputation of the service provider. Perceived service is the actual experience of a consumer after receiving a service, which is influenced by the provider's activities. The service provider related issue is expressed in the bottom part. During the service transaction, the managers' awareness of customer expectations plays a guiding role in determining the organizational service quality standards. In addition, it is also affected by corporate marketing communication activities with consumers (Parasuraman et al., 1985, 1988). The GAP model identifies five main causes of unsuccessful delivery described as below (Parasuraman et al. 1985, 1988):

Gap 1: Expectation-perception gap, which is the difference between consumers' expected service and the service provider's perceptions of the expectations.

Gap 2: Quality specification gap, which is the difference between service provider's perception and the customer perception in service quality specification.

Gap 3: Service performance gap, which is the difference between the service strandrads and the actual delivery.

Gap 4: Market communication gap, which is the difference between the actual delivered service and the commitment to customers.

Gap 5: Perceived service quality gap, which is the difference between the actual service perception and the expectation of service by consumers.

The gaps are shown in Fig. 3.

One of the objectives in this research is to measure gap 5 (the difference between actual service perception (P) and expectation of service (E) or P-E) in order to understand the influences of service quality on consumer satisfaction among Turkish students in Malaysian HEIs. The gap is also known as disconfirmation, i.e. the discrepancy between expectations and actual experiences (Oliver 1980).

In explaining the disconfirmation theory, Satari (2007) and Ekinci (2004) observed that customers after experiencing a service would compare their perception of the service's performance against their expectations, before experiencing the service. When $\mathrm{P}$ is greater than or equal to $\mathrm{E}$, then customer satisfaction (CS) or positive disconfirmation occurs ( $\mathrm{P} \geq \mathrm{E} \rightarrow \mathrm{CS}$ ). But negative disconfirmation or customer dissatisfaction (CD) would occur if $\mathrm{P}$ is less than $\mathrm{E}(\mathrm{P}<$ $\mathrm{E} \rightarrow \mathrm{CD}$ ). What should be noted here is that, customer satisfaction occurs by confirmation of consumers' expectations whereas disconfirmation of consumers' expectations will cause dissatisfaction. This is illustrated in Figure 4.

\section{Satisfaction}

Satisfied customers are more likely to respond positively and recommend the business to others. Oliver (1981) defined satisfaction as the sense responded by the disconfirmation experience of consumption, which plays a role as the base approach level. Schoepp (2010) put forward a definition in an oversea students context, which is a feeling that the international students may or may not achieve the expectations of faculty with regards to issues they faced such as university culture or living in the host country.

Hampton (1983) indicated that the marketing orientation of a higher education institution requires that the students are viewed as the consumers of educational service who have specific needs and wants. According to Kotler (1984), understanding consumer satisfaction is at the core of a marketing orientation and practice. According to Seymour (1993), the phrase "The customer is always right" can be easily evoked in the education industry when some faculty members start to believe that the end result of a student-customer orientation is about pandering to students or lowering academic standards. In this 
aspect, Ewell (1993) suggested that educators ought to view knowledge not as "a service" to anyone; it should be independent from the "threat" of viewing students as customers. In fact, knowledge is the goal, not satisfaction.

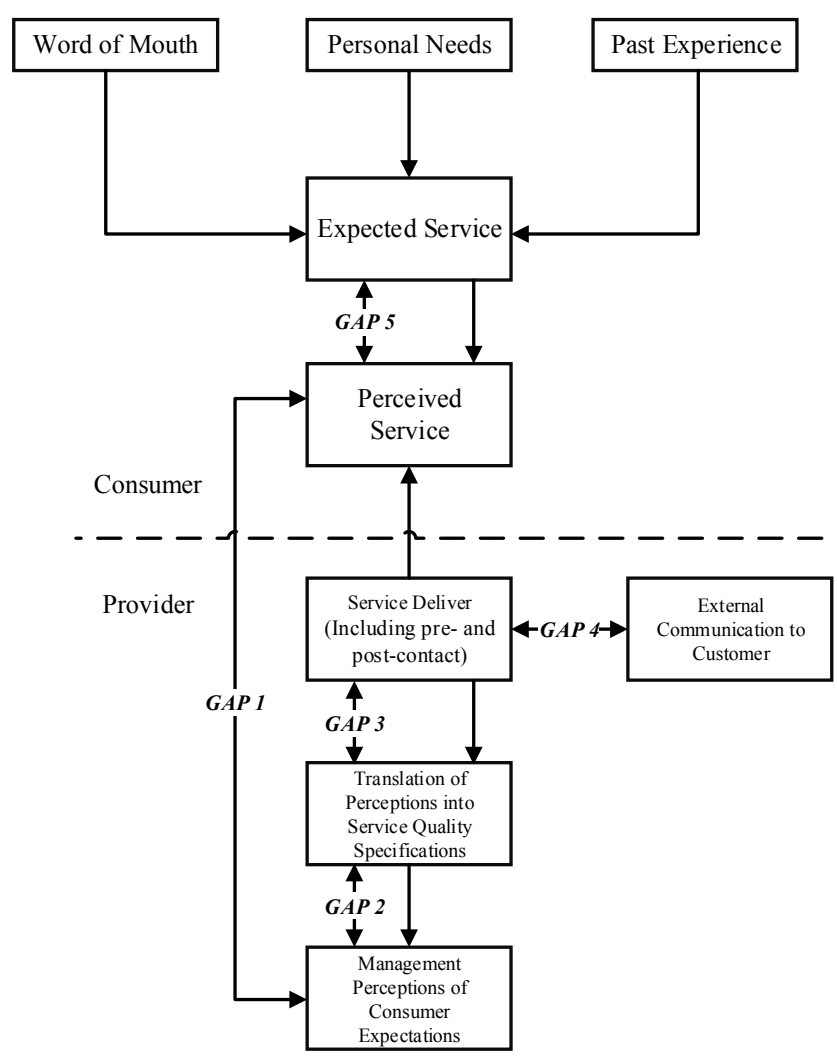

Fig. 3. GAP Model

Source: Parasuraman et al. $(1985,1988)$

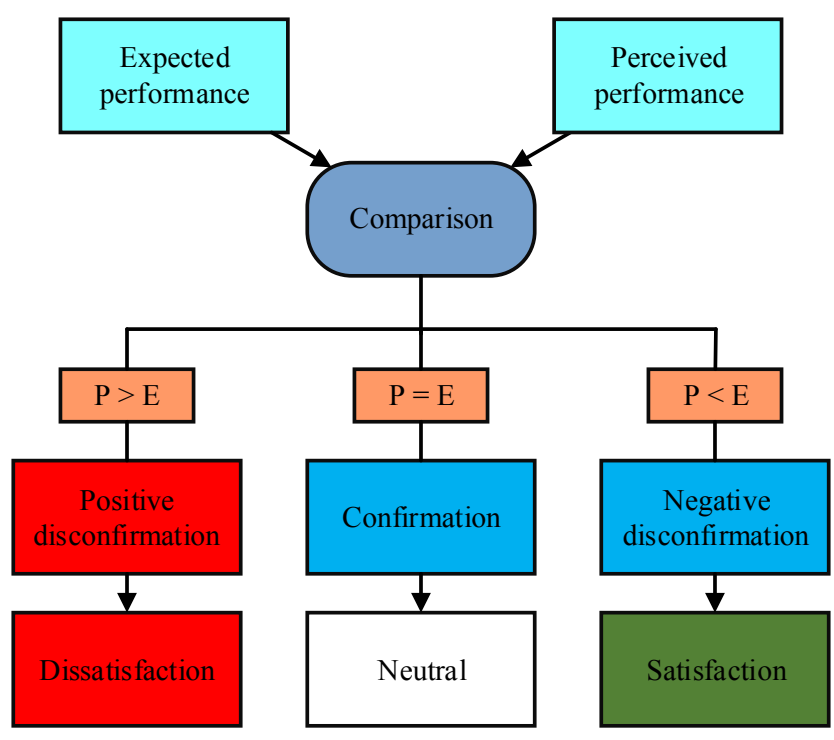

Fig. 4. Expected Disconfirmation Theory Model

Source: Ekinci, Y. (2004). An investigation of the determinants of customer Satisfaction, Tourism Analysis

\section{Service quality and customer satisfaction in higher education}

In reviewing the theories on satisfaction, three elements are common: (1) type of responses (i.e. cognitive or emotional); (2) whether the response concerns a particular focus (for example expectations and consumption experience); and (3) if the satisfaction occurs at a given time (Giese and Cote, 2000). Many scholars have argued in favour of the students - as - customers perspective in higher education (Chadwick and Ward, 1987; Christenses and Philbrick, 1993, Franklin and Shemwell, 1995; Bejou, 2005; Ahmed et al. 2010; Watjatkarul, 2010; Lu H, et al. 2013 ) and thus, uses the disconfirmation theory to measure antecedents of satisfaction - that is satisfaction as a function of the size and direction of the disconfirmation experience, where disconfirmation is a function of the gap between customers' expectations and perceptions (Churchill and Suprenant, 1982; Tse and Wilton, 1988; Henning- Thurau, 2001; Brady and Robertson, 2001Powers and Valentine, 2008).

Cronin and Taylor (1992) noted that service quality has been a major factor of ensuring satisfaction with products and services offered by organisations. In this regard, the association between service quality and customer satisfaction has been a topical issue addressed by researchers, and it has great implication. Overall, perceived service quality is an antecedent to satisfaction, and as such, organisations including higher education institutions, need to find out those factors that could lead to satisfaction (Lassar et al. 2000).

Early and recent studies had established divergent views on service quality and customer satisfaction. While Bitner, (1990) and Parasuraman, et al. (1988) argued that customer satisfaction is an antecedent of service quality, others believed that it is service quality that leads to customer satisfaction and behavioural intentions (Chia et al. 2008; Ott. 2008; Molinari et al. 2008). Some scholars claimed that that service quality leads to satisfaction (McDougall and Levesque, 1996, 2000; Negi, 2000) thereby questioning the claim by Cronin and Taylor (1992) who posit that satisfaction causes quality. However, Parasuraman et al. (1988:16) argued that service quality and satisfaction are different constructs and concluded that "satisfaction is an antecedent of service quality". Since customer satisfaction can be related to service quality, the two constructs cannot be viewed as single construct (Bitner, 1990). According to Parasuraman et al. (1988), what is being measured is attitude relating to the transaction situations experienced by the customer over a given period.

However, the importance of students' satisfaction will be appreciated by asking: "What follows if students, as customers, are dissatisfied?" It is apparent that, in a competitive service environment, students who are dissatisfied may tend to withdraw or transfer (Hayes, 1977; Souter and McNeil, 1996). But in the event that, the students, because of absence of a viable alternative, decide to remain in the institution, they may not speak well of it, and thus affecting positive word-ofmouth referrals to future students.

Because of growing competition, higher education institutions, particularly technological universities in Nigeria, need to understand their service quality performance in order to develop marketing strategies to attract and retain students. It should be noted that, what drives customer satisfaction are two-fold: (1) satisfaction with individual services across all dimensions, (2) overall satisfaction (Bitner et al. 2000), meaning that customers would get satisfaction with a specific dimension of a service, as well as an overall opinions of customers regarding what has been provided (Parasuraman et al. 1988)

Also, Negi (2009) posits that significant relationship exist between total service quality and customer satisfaction. According to Saravanan and Rao (2007), customer satisfaction is based on the level of service quality delivered by the service provider, and is determined by the customer's overall experiences with the service encounter (Cicerone et al. 2009). Thus, overall satisfaction should be seen as the totality of what higher education institutions provides to students in terms of the overall learning experiences. The aforementioned arguments shows that service quality and customer satisfaction are not single construct, but there exist a relationship between the two constructs (Wicks and Roethlein, 2009).

\section{Methodology}

In this study, a questionnaire survey served as the survey instrument for data collection. Selected Turkish students were required to read and understand the questions, and then writing down 
their options (Mitchell and Jolley, 2010). The questionnaire consisted of four sections, section A was adopted from Reynolds's (2010) study on expatriate sociocultural adjustment which consists of 11 items anchored on a 5-point scale where by $1=$ unable to adjust at all and 5 $=$ able to adjust completely, Section B was adopted from Rasli's (2013) study on service quality gaps among Iranian postgraduate students which consists of 35 items with two separate sub-sections anchored on five-point Likert scales arranged side by side, Section C was adopted from Shekarchizadeh, Rasli and Hon-Tat (2011) study on university students satisfaction comprising of 6 items anchored on five-point Likert scales, and section D contained demographic items. A pilot testing of the questionnaire was then executed among a group of 10 international students in UTM as per the recommendations of Oppenheim (1992). The survey questionnaire was then refined, and the finalized questionnaire was distributed to the selected Turkish students using face-to-face method.

The data collected were then analyzed using the descriptive analysis and the single mean t-tests to assess the levels of adjustment, service quality and satisfaction among the Turkish students. Each of the items in the first section is anchored on a five-point Likert scale to measure the respondent's agreement to the item posed. According to Buttle (1996), SERVQUAL gap can be determined based on three methods: (a) item-by-item analysis (e.g., P1 - E1, P2 - E2, . . .P35- E35); (b) dimension-by-dimension analysis based on the means (e.g., $(\mathrm{P} 1+\mathrm{P} 2$ $+\mathrm{P} 3+\mathrm{P} 4) / 4-(\mathrm{E} 1+\mathrm{E} 2+\mathrm{E} 3+\mathrm{E} 4) / 4)$, where $\mathrm{P} 1$ to $\mathrm{P} 4$, and E1 to E4 represent the four perception and expectation statements relating to a particular dimension); and (c) computation of an overall mean of service quality construct $[(\mathrm{P} 1+\mathrm{P} 2+\mathrm{P} 3 \ldots+\mathrm{P} 35) / 35]-(\mathrm{E} 1+\mathrm{E} 2+$ $\mathrm{E} 3+\ldots+\mathrm{E} 35) / 35])$. The researchers decided to use the first two methods of measuring SERVQUAL gaps in this study to obtain both micro and macro perspectives of the gaps within the five dimensions. Adjustment consists of 13 items representing 3 dimensions: cultural, interaction and studying, while satisfaction comprise of 5 items. Additionally, the means for the dimensions of adjustment and satisfaction were also calculated accordingly. Subsequently, tests for statistical reliability using Cronbach's alphas for the five constructs were conducted, following which a series of single mean t-tests was conducted to analyze the levels of SERVQUAL gaps, the adjustment dimensions and satisfaction.

There are a few Malaysian universities that the Turkish ministry of higher education accredited of which UTM is one of them and has a sizeable number of Turkish students. As such, UTM was chosen as the research site. The population of Turkish students at UTM is 65, and 41 were chosen using stratified sampling based on gender to ensure fair representation of the population. Distribution of the questionnaire to the identified respondents was via face-to-face to facilitate data collection and to ensure all items in the questionnaires were answered.

\section{Findings}

Of the data collected at UA, all 41 were deemed as unusable due to the completeness of responses to all the questionnaire items. With reference to Table 2, about $73.2 \%$ of the respondents are male and $78 \%$ are undergraduate students. Also, a large percentage $(78 \%)$ of the student respondents is less than 25 years old. Finally, a majority of the respondents are studying engineering $(51.2 \%)$ as UA is a reputable technical university in Malaysia.

\begin{tabular}{lll}
\multicolumn{3}{l}{ Table 2: Demographic Background of Respondents } \\
\hline \multicolumn{2}{l}{ Demographic Background } & UA \\
\hline Gender & Male & 30 \\
& Female & 11 \\
Program & Undergraduate & 32 \\
& Postgraduate & 9 \\
Age & $20-25$ years & 32 \\
& $25.01-30$ years & 7 \\
\multirow{2}{*}{ Major } & $30.01-35$ years & 2 \\
& Social science & 12 \\
& Life sciences & 8 \\
& Engineering & 21 \\
\hline
\end{tabular}

Table 4: Mean Scores of Respondents' Perceptions on Adjustment

\begin{tabular}{|c|c|c|c|c|c|}
\hline \multirow[t]{2}{*}{ Dimension } & \multirow[t]{2}{*}{ Attribute } & \multicolumn{4}{|c|}{ Test Value $=3$} \\
\hline & & $\mathbf{t}$ & Df & Sig. (2-tailed) & Mean \\
\hline \multirow[t]{7}{*}{ Basic } & Living conditions in general & 1.000 & 40 & .323 & 3.19512 \\
\hline & Housing conditions & 1.280 & 40 & .208 & 3.24390 \\
\hline & Food choice and taste & 1.816 & 40 & .077 & 3.39024 \\
\hline & Shopping options & -1.000 & 40 & .323 & 2.80488 \\
\hline & Cost of living & 3.037 & 40 & .004 & 3.63415 \\
\hline & Entertainment and recreation facilities and opportunities & -.723 & 40 & .474 & 2.8537 \\
\hline & Health care facilities & -8.929 & 40 & .000 & 1.6098 \\
\hline \multirow[t]{2}{*}{ Interaction } & Interacting with others on a day to- day basis & -2.045 & 40 & .047 & 2.5366 \\
\hline & Interacting with Malaysians on a day to- day basis & -2.175 & 40 & .038 & 2.5206 \\
\hline \multirow[t]{2}{*}{ Studying } & My specific academic responsibilities & -1.856 & 40 & .071 & 2.5366 \\
\hline & Performance standards and expectations of my academic work & 2.761 & 40 & .009 & 3.46341 \\
\hline
\end{tabular}

Table 5: Mean Scores of Respondents' Perceptions on Satisfaction Attributes of Satisfaction

Overall, I am pleased with my experience at this university where I am studying now Overall, I am pleased with service quality at this university where I am studying now I would choose this university again for further studies (e.g. post-doctoral)

I would choose this university for another degree (for example after completing your PHD in engineering you could continue to do your MBA in the same university)

I would recommend this university to a friend, relative, or other potential Turkish student

I would consider making a financial gift to this university where I am studying now

now

\begin{tabular}{lcl}
\multicolumn{3}{l}{ Test Value $=\mathbf{3}$} \\
$\mathbf{t}$ & Df & Sig. (2-tailed) \\
3.447 & 40 & .001 \\
2.672 & 40 & .011 \\
.443 & 40 & .660 \\
.304 & 40 & .762 \\
& & \\
-.260 & 40 & .796 \\
-4.060 & 40 & .000
\end{tabular}

Mean
3.6341
3.5122
3.0976
3.0732

2.9512
2.1951

\section{Conclusions and recommendations}

Similar trend with Turkish students in Europe and American universities has been observed during the study like the majority of the respondents in this research are male students. Reason for Low Turkish female rate in international universities could be Turkey's traditional norms and religious values, in which there is a higher likelihood for males to go abroad for higher education than females (Mehdizadeh and Scott, 2005).
As service Quality Measurement scale (SERVQUAL) has been modified, so reliability statistics indicated sufficient internal consistency of constructs. This finding conforms to previous studies by Yang (2008), Harris (2002), Ham and Hayduk (2003) and Ruby (1996).

Results exposed high expectations of the Turkish students regarding service quality in higer education in Malaysia but low perception value indicated a negative gap of service quality, which reflects dissatisfaction of Turkish Students studying at Malaysia. The negative values indicate dissatisfaction (Shekarchizadeh et al., 2011) with the education service quality on all the five aforementioned service 
quality factors and their respective dimensions. One of the most important causes for feeling this dissatisfaction could be explained by gap theory (Parasuraman et al., 1985). The gap theory suggests that the difference between consumers' expectations about the performance of a general class of service providers and their assessments of the actual performance of a specific provider within that class will drive the perception of service quality. This negative gap may be caused by comparison of Malaysian universities with American and European universities by the Turkish students The authors speculate that Malaysian universities may lack the support services for international students' universities must become more knowledgeable about the adjustment issues these students face and implement appropriate support services. According to Güngör and Tansel, (2005), Turkey is also among the top ten in terms of the number of students studying in US higher education institutions. The tendency to compare the service quality between the Malaysian university and Western universities may result in this shortcoming. Study recommends that Malaysian Universities needs to improve service quality of the Malaysian Universities so they can compete in global competition and to retain International students. Study proposed for the improvements in the higher education service quality Malaysian universities needs to focus on the five basic dimensions of the service quality which leads to ultimate service quality for the satisfaction of all international students.

Study also provides food for thought to the upcoming researchers to investigate basic factors for dissatisfactions of international students at Malaysian Universities.

\section{References}

Acuma Incorporated (November, 2009). Multicultural Malaysia a Hit by Foreign Students, Available from http://www.acuma.org.au.

Amran Rasli, Ahmadreza Shekarchizadeh and Muhammad Jawad Iqbal (2012). Perception of Service Quality in Higher Education: Perspective of Iranian Students of Malaysian Universities, International Journal of Economics and Management, 6(2): $201-220$.

Angell, R.J., Heffernan, T.W. and Megicks, P. (2008). Service Quality in Postgraduate Education, Quality Assurance in Education, 16(3), 236-254.

Ayob, M. and Yaakub, F. (2000). Development of Graduate Education in Malaysia: Prospects for Internationalization. ASAIHL Seminar on University and Society: New Dimensions for the Next Century Proceeding, Naresuan University, Phitsanulok, Thailand. Available from: $\mathrm{http}: / /$ mahdzan.com/papers/thaipaper00/default.asp.

Black, J.S. and Gregersen, H.B. (1991). The other half of the picture: Antecedents of Spouse Cross-cultural Adjustment, Journal of International Business Studies, 3(22), 461-477.

Brady, M.K. and Robertson, C.J. (2001). Searching for a Consensus on the Antecedent Role of Service Quality And Satisfaction, Journal of Business Research, 51(1), 53-60.

Buttle, F. (1996). SERVQUAL: Review, Critique, Research Agenda, European Journal of Marketing, 30(1), 8-32.

Clark, N. and Mihael A. (2012). Education in Turkey. World Education News \& Reviews. Available from: https://www.wes.org/ewenr/12sept/feature.htm.

Cronin, J.J. and Taylor, S.A. (1992). Measuring Service Quality: a Reexamination and Extension. Journal of Marketing, 56, 55-68.

Denman, B.D. (2005). What is a University in the 21 st century? Higher Education Management and Policy, 17, 9-28.

Donthu, N. and Yoo, B. (1988). Cultural Influences on Service Quality Expectations, Journal of Service Research, 1(2), 178-186.

Duru, E. and Poyrazli, S. (2007). Personality dimensions, psychosocialdemographic variables, and English language competency in predicting level of acculturative stress among Turkish international students. International Journal of Stress Management, 14, 99-110.

Edufairs (2013). Why Do Turkish Students Study Abroad? Available from http://www.edufairs.net/university/why-turkish-students-study-abroad.

Farley, J. and Lehmann, D. (1994). Cross-cultural Laws and Differences in Market Response, Management Science, 40(1), 111-122.

Farouk, O. (2002). The September 11 Mega-Terrorism and Its Impact on Malaysia. JAMS News No.22, pp.6-12.

Gibbons, M. (1998) Higher Education Relevance in the 21st Century, the World Bank contribution to the UNESCO World Conference on Higher Education Proceeding, Paris, October 5-9, 1998.

Güngör. N.D. and Tansel, A. (2005). The Determinants of Return Intentions of Turkish Students and Professionals Residing Abroad: An Empirical
Investigation, Discussion Paper Series. Forschungsinstitut zur Zukunft der Arbeit Institute for the Study of Labor.

Ham, C.L. (2003). Service Quality, Customer Satisfaction, and Customer Behavioral Intentions in Higher Education. Unpublished PhD thesis, Nova Southern University.

Ham, C.L. and Hayduk, S. (2003). Gaining Competitive Advantages in Higher Education: Analyzing the Gap Between Expectations and Perception of Service Quality, International Journal of Value-Based Management, 16(3), 223-242.

Hanafi Atan, Mohamed Amin Embi, Supyan Hussin (2011). e-Learning Policy in Malaysian Higher Education Institutions. In Mohamed Amin Embi, eLearning in Malaysian Higher Education Institutions: Status, Trends, \& Challenges (pp. 5-18). Putrajaya: Department of Higher Education Ministry of Higher Education.

Harris, B.L. (2002). A Study of Service Quality: Gap Analysis of Expectations Versus Performance Perceptions of Junior, Senior, and Graduate Students. Unpublished PhD thesis, University of Alabama.

Harris, R. W. (2007). Telecentre evaluation in the Malaysian context. Paper presented at the 5th International Conference on IT in Asia, 10-12 July 2007, Kuching, Sarawak, Malaysia.

Harvey, L. and Knight, P.T. (1996) Transforming Higher Education. London: Open University Press.

IDEAS. (2008). Selangor Set to be Education Hub: The Quest for the Highest Quality Education in This State is Under Way.

Qureshi M I, Khan A and Zaman K (2012), Structural Investigation of Service Quality in Conventional and Islamic Banking in Pakistan. Industrial Engineering Letters, Vol 2, No.2, 11-17

Qureshi M I, Bhatti M N and Zaman K (2012), Quality Function Deployment in Higher Education Institutes of Pakistan, Middle-East Journal of Scientific Research 12 (8): 1111-1118,

Jimenez, E.Y. (2007) Malaysia and the Knowledge Economy: Building a World-class Higher Education System, Report No. 40397-MY, The World Bank.

Johari, M.M.N., Abdullah, A.A.A., Osman, M.R., Sapuan, M.S. Marioun, N., Jaafar, M.S. (2002) A New Engineering Education Model for Malaysia, International Journal of Engineering Education, 18(1), 8-16.

Karakaya, I. and Tavşancil, E. (2008). The Predictive Validity of the University Student Selection Examination. Educational Sciences: Theory \& Practice, 8 (3), 1011-1019.

Lee, J. (2007). SERVQUAL vs SERVPERF: Round 2 in a Multi-cultural Setting, The Free Library. Available from: http://www.thefreelibrary.com/SERVQUAL vs SERVPERF: round 2 in a multi-cultural setting-a0172010692.

Leggott, D. and Stapleford, J. (2007) Internationalisation and employability, in S. Brown \&E. Jones (Eds.), Internationalising higher education: Enhancing teaching, learning and curriculum. London: Routledge.

$\mathrm{Lu} \mathrm{H}$, Chu Y, Li T and Wang Q (2013). Analysing the factors influencing learners' knowledge sharing behaviour in the virtual learning community of a faculty training programme, Int. J. Cont. Engineering Education and Life-Long Learning, Vol. 23, Nos. 3/4, 251-266

Markovic, S. (2005). Student's Expectations and Perceptions in Croatian Tourism and Hospitality Higher Education: SERVQUAL versus UNIQUAL. South East European Journal of Economics and Business, 1(2): 78-96.

McPherson, C. (2013). Reasons for choosing educational opportunities abroad. Available from: www.todayszaman.com/columnist-309514reasons-for-choosing-educational-opportunities-abroad.html.

Mehdizadeh, N and Scott, G. (2005). Adjustment problems of Turkish international students in Scotland, International Education Journal, 2005, 6(4), 484-493.

Mehmet Tuğcu (2010). Education: a competitive market. Daily News 6/22/2010. Available from http://www.hurriyetdailynews.com/default.aspx?pageid=438\&n=educatio n-a-competitive-market-2010-06-22.

Ministry of Higher Education Malaysia (2006). The Report by the Committee to Study, Review and Make Recommendations Concerning the Development and Direction of Higher Education in Malaysia, Ministry of Higher Education Malaysia: Putrajaya.

Ministry of Higher Education Malaysia (2008). Buku Perangkaan, Ministry of Higher Education Malaysia: Putrajaya.

Naidoo, V. (2009). Transnational Higher Education: A Stock Takes of Current Activity, Journal of Studies in International Education, 13(3), 310-330.

Najera, I.J. (1990). The Relationship of acculturation and acculturative stress to college environmental stress, college satisfaction, and self-esteem among Hispanic undergraduates at selected Ohio universities'. Unpublished PhD, The Ohio State University.

Parasuraman, A., Zeithaml, V. and Berry, L. (1985). A Conceptual Model of Service Quality and Its Implications for Future Research, Journal of Marketing, 49, 41-50. 
Parasuraman, A., Zeithaml, V. and Berry, L. (1988). SERVQUAL: A Multiple Item Scale for Measuring Customer Perceptions of Service Quality, Journal of Retailing, 64(1), 12-40.

Parasuraman, A., Zeithaml, V. and Berry, L. (1994). Alternative Scales for Measuring Service Quality: A Comparative Assessment Based on Psychometric and Diagnostic Criteria, Journal of Retailing, 70(3), 201230 .

Parasuraman, A., Zeithaml, V. and Berry, L. (1997). Multiple-method Listening: The Building of A Service Quality Information System, Sloan Management Review, April, 65-76.

Ruby, C. (1996). Assessment of Student Satisfaction with Selected Student Support Services Using the SERVQUAL Model of Customer Satisfaction. Unpublished $\mathrm{PhD}$ Dissertation, Ohio University.

Shahin, A. (2008). SERVQUAL and Model of Service Quality Gaps: A Framework for Determining and Prioritizing Critical Factors in Delivering Quality Services. Available from: http://www.scribd.com/doc/8486222/ Servqual-a-Shahin.

Shekarchizadeh, A., Rasli, A., Huam, H.T. (2011). SERVQUAL in Malaysian Universities: Perspectives of International Students, Business Process Management Journal, 17(1), 67 - 81 .
Sirat, M. (2006). Malaysia. In, S. Shaeffer And S. Yavaprabhas (eds.) Higher Education in South Asia. The UNESCO Asia and Pacific Regional Bureau For Education: Bangkok, Thailand.

Smith, E.C. And Luce, L.F. (1979) Toward Internationalism: Readings in Cross-cultural Communication. Rowley: Newburg House Publishers.

Tham, C. L. (2009). 30 Per Cent Jump in Mainland Chinese Students in Malaysia. Available from http://www.bernama.com/bernama/v5/newsindex.php?id=380381.

Tomasz A. Walasek and Zygmunt Kucharczyk (2014), Quality management in e-courses, Int. J. Cont. Engineering Education and Life-Long Learning, Vol. 24, No. 1,6-21

Toncich, D. (2006). Key Factors in Postgraduate Research: a Guide for Students. Chrystobel Engineering: Brighton, Australia.

UNESCO (2009). Trends in Global Higher Education. Paris, France: UNESCO.

Yang, L.M. (2008). An Examination of Education Service Quality at Collegiate Physical Education Departments in Taiwan: Using a Gap Analysis Approach. Unpublished PhD thesis, United States Sports Academy.

Yeo, R.K. (2008). Brewing Service Quality in Higher Education. Quality Assurance in Education, 16(3), 266-286. 


\begin{tabular}{|c|c|c|c|c|c|}
\hline Dimension & Statement & $\begin{array}{l}\text { Mean } \\
\text { Expected } \\
\text { Service }\end{array}$ & $\begin{array}{l}\text { Perceived } \\
\text { Service }\end{array}$ & $\begin{array}{l}\text { Gap } \\
\text { Score }\end{array}$ & p-value \\
\hline \multirow[t]{5}{*}{ Tangible } & Uses modern equipment and technology (Q1) & 4.27 & 2.95 & -1.32 & 0.000 \\
\hline & Physical facilities visually appealing (Q2) & 4.22 & 3.15 & -1.07 & 0.000 \\
\hline & Materials visually appealing (Q3) & 4.56 & 3.27 & -1.29 & 0.000 \\
\hline & Support staff are well dressed (Q8) & 4.44 & 3.10 & -1.34 & 0.000 \\
\hline & Members of faculty are well dressed (Q22) & 4.46 & 3.80 & -0.66 & 0.000 \\
\hline \multicolumn{2}{|c|}{ Overall tangible gap } & 4.39 & 3.25 & -1.14 & 0.000 \\
\hline \multicolumn{2}{|c|}{ Cronbach's alpha } & 0.793 & & & \\
\hline \multirow[t]{8}{*}{ Reliability } & Promised to do something and did so (Q4) & 3.80 & 2.73 & -1.07 & 0.000 \\
\hline & Showed honest interest solving your problem (Q5) & 3.95 & 2.63 & -1.32 & 0.000 \\
\hline & Support staff provided services at time promised (Q9) & 3.78 & 2.37 & -1.41 & 0.000 \\
\hline & Support staff performed service right first time (Q10) & 3.93 & 2.39 & -1.54 & 0.000 \\
\hline & Support staff maintained error free records (Q11) & 3.51 & 2.46 & -1.05 & 0.000 \\
\hline & Faculty provided services at time promised (Q23) & 4.37 & 3.61 & -0.76 & 0.000 \\
\hline & Faculty performed service right first time (Q24) & 4.39 & 3.44 & -0.95 & 0.000 \\
\hline & Faculty maintained error free records (Q25) & 4.34 & 3.40 & -0.94 & 0.000 \\
\hline \multicolumn{2}{|c|}{ Overall reliability gap } & 4.01 & 2.88 & -1.13 & 0.000 \\
\hline \multicolumn{2}{|c|}{ Chronbach's alpha for reliability items } & 0.873 & & & \\
\hline Responsivene & Staff told exactly when services were done (Q12) & 3.63 & 2.49 & -1.14 & 0.000 \\
\hline \multirow[t]{7}{*}{ ss } & Support staff gave prompt service to you (Q13) & 4.32 & 2.49 & -1.83 & 0.000 \\
\hline & Staff willing to help (Q14) & 3.90 & 2.73 & -1.17 & 0.000 \\
\hline & Support staff respond to requests all the time (Q15) & 3.61 & 2.66 & -0.95 & 0.000 \\
\hline & Faculty told exactly when services were done (Q26) & 4.39 & 3.37 & -1.02 & 0.000 \\
\hline & Faculty gave prompt services to you (Q27) & 4.31 & 3.49 & -0.82 & 0.000 \\
\hline & Faculty readily helped (Q28) & 4.37 & 3.49 & -0.88 & 0.000 \\
\hline & Faculty responded to requests promptly (Q29) & 4.41 & 3.23 & -1.18 & 0.000 \\
\hline \multicolumn{2}{|c|}{ Overall responsiveness gap } & 4.12 & 2.99 & -1.12 & 0.000 \\
\hline \multicolumn{2}{|c|}{ Chronbach's alpha for responsiveness items } & 0.897 & & & \\
\hline \multirow[t]{7}{*}{ Assurance } & Felt safe in learning environment (Q6) & 4.34 & 3.37 & -0.97 & 0.000 \\
\hline & Support staff behavior instilled confidence in you (Q16) & 3.93 & 2.54 & -1.39 & 0.000 \\
\hline & Support staff are consistently courteous to you (Q17) & 3.93 & 2.56 & -1.37 & 0.000 \\
\hline & Support staff have the knowledge to answer your questions (Q18) & 3.98 & 2.41 & -1.57 & 0.000 \\
\hline & Faculty behavior instilled confidence in you (Q30) & 4.41 & 3.15 & -1.26 & 0.000 \\
\hline & Faculty consistently were polite with you (Q31) & 4.39 & 3.49 & -0.90 & 0.000 \\
\hline & Faculty had knowledge to answer your questions (Q32) & 4.41 & 3.51 & -0.90 & 0.000 \\
\hline \multicolumn{2}{|c|}{$\begin{array}{l}\text { Overall assurance gap } \\
\text { Chronbach's alpha for assurance items }\end{array}$} & $\begin{array}{l}4.19 \\
0.887\end{array}$ & 3.00 & -1.19 & 0.000 \\
\hline \multirow[t]{7}{*}{ Empathy } & Operating hours were convenient for you (Q7) & 4.27 & 3.20 & -1.07 & 0.000 \\
\hline & Support staff gave you individual attention (Q19) & 3.90 & 2.61 & -1.29 & 0.000 \\
\hline & Staff had your best interests in heart (Q20) & 4.32 & 2.59 & -1.73 & 0.000 \\
\hline & Support staff understood your specific needs (Q21) & 3.39 & 2.44 & -0.95 & 0.000 \\
\hline & Faculty gave you individual attention (Q33) & 4.37 & 3.44 & -0.93 & 0.000 \\
\hline & Faculty had your best interests at heart (Q34) & 4.37 & 3.30 & -1.07 & 0.000 \\
\hline & Faculty understood your specific needs (Q35) & 4.32 & 3.22 & -1.10 & 0.000 \\
\hline \multicolumn{2}{|c|}{$\begin{array}{l}\text { Overall empathy gap } \\
\text { Chronbach's alpha for empathy items }\end{array}$} & $\begin{array}{l}4.13 \\
0.889\end{array}$ & 2.97 & -1.16 & 0.000 \\
\hline
\end{tabular}

